\title{
The population, protein profile and ultrastructure of Ascaridia galli in chicken treated using Areca catechu crude aqueous extract
}

\author{
W. W. Mubarokah ${ }^{1}$, W. Nurcahyo ${ }^{2}$, J. Prastowo ${ }^{2}$ and K. Kurniasih ${ }^{3}$,* \\ ${ }^{1}$ Department of Animal Health, Agriculture Extension College, The Polytechnique of Agricultural \\ Development of Yogyakarta Magelang, Jalan Magelang-Kopeng Km 7 Purwosari, Tegalrejo, \\ Magelang, Central Java 56192 - Indonesia \\ ${ }^{2}$ Department of Parasitology, Faculty of Veterinary Medicine, Universitas Gadjah Mada, \\ Bulaksumur Sleman, Yogyakarta, 55281 - Indonesia \\ ${ }^{3}$ Department of Pathology, Faculty of Veterinary Medicine, Universitas Gadjah Mada, Bulaksumur \\ Sleman, Yogyakarta, 55281 - Indonesia \\ *Corresponding E-mail: kurniasih_1951@yahoo.co.id
}

Received September 09, 2019; Accepted November 18, 2019

\begin{abstract}
ABSTRAK
Penelitian ini bertujuan untuk mengetahui populasi, profil protein dan ultrastruktur cacing dewasa dalam usus halus ayam kampung yang diberikan infusa biji buah pinang. Sebanyak 50 ekor ayam betina berumur 6 minggu dibagi dalam 5 kelompok. Kelompok A (kontrol negatif) tidak diberi perlakuan dan tidak diobati. Kelompok B, C dan D masing-masing diberi perlakuan dosis $26 \mathrm{mg} / \mathrm{mL}, 53 \mathrm{mg} / \mathrm{mL}$ dan 79 $\mathrm{mg} / \mathrm{mL}$. Kelompok E (kontrol positif), diberi Pyrantel®). Semua ayam dinekropsi 14 hari setelah perlakuan. Cacing dewasa dikoleksi dan dihitung. Cacing yang digunakan pada SDS-PAGE dan Scanning Electron Microscopy (SEM) adalah cacing hasil koleksi dari jejenum ayam kelompok A, B dan C. Jumlah cacing tertinggi ditemukan pada bagian jejenum. Hasil elektroforesis menyatakan bahwa dosis $53 \mathrm{mg} / \mathrm{mL}$ menghasilkan lebih sedikit pita protein dibandingkan kontrol negatif (21 banding 12) sedangkan pada SEM ditemukan kerusakan kutikula dan abrasi bagian anterior bibir pada dosis 53 $\mathrm{mg} / \mathrm{mL}$. Kesimpulan: infusa biji buah pinang menunjukkan potensi aktifitas anthelmentik dengan mengurangi jumlah, mengurangi profil protein dan merusak cacing dewasa $A$. galli pada usus halus.

Kata kunci: Ascaridia galli, biji buah pinang, SEM, SDS-PAGE
\end{abstract}

\begin{abstract}
The study aimed at investigating the population, the protein profile and the ultrastructure of adult worms in the intestine of domestic chicken treated using Areca catechu crude aqueous extract. Fifty domestic female chickens of 6 weeks of age were assigned to 5 groups. Group A (negative control) was not given any treatment and any drug. Groups B, C and D were given the treatment at the doses of 26 $\mathrm{mg} / \mathrm{mL}, 53 \mathrm{mg} / \mathrm{mL}$ and $79 \mathrm{mg} / \mathrm{mL}$, respectively. Group E (positive control) was given Pyrantel ${ }^{\circledR}$. Necropsy was conducted to all of the chickens 14 days after the treatment. Adult worms were collected and counted. The worms used in Sodium Dodecyl Sulfate Polyacrylamide Gel Electrophoresis (SDSPAGE) and Scanning Electron Microscopy (SEM) were those collected from the jejunum of the chickens in the groups A, B and C. The biggest number of the worms was found in the jejunum. The results of electrophoresis showed that the dose $53 \mathrm{mg} / \mathrm{mL}$ gave fewer protein bands than the negative control (21:12 ratio), while the results of the SEM showed that there was cuticle damage and anterior labia abrasion at the dose of $53 \mathrm{mg} / \mathrm{mL}$. The Areca catechu crude aqueous extract showed anthelmintic
\end{abstract}


activity potential by reducing the number of the adult worms, lowering their protein profile and damaging the $A$. galli worms in the intestine.

Keywords: Ascaridia galli, Areca catechu, SEM, SDS-PAGE

\section{INTRODUCTION}

Ascaridia galli is the most common species of nematodes found in poultry all over the world. Alkharigy et al. (2018) suggest that the prevalence of $A$. galli worms in Tripoly, Libya is up to $22 \%$. Ascaridia galli infects millions of poultry that it inflicts economic loss both in commercial farm and people's farm (Balqis et al., 2017). Helminthiasis control in chicken is still carried out using chemoprophylaxis method (synthetic anthelmintics). The treatment of the synthetic anthelminics is expensive and it inflicts following losses: environmental pollution, influencing hospes' health, and causing resistance (Vercruyssea et al., 2011).

One of the methods to overcome the problem is to find alternative anthelminics resulting from natural substances with efficacious anthelmintics against Ascaridia galli, such as ginger (Zingiber officinale) and turmeric (Curcuma longa) (Bazh and El Bahy, 2013); pineapple leaves (Ananus comosus) (Akter et al., 2016); squash seeds (Cucurbita pepo) and pomegranate peels (Punica granatum) (Aziz et al., 2018); Acanthus ilicifolius (Husori et al., 2018); and Iris kashmiriana Linn. (Khan et al., 2018).

In general, the parameters of in vivo study include the decrease in egg per gram (EPG) value (Bazh and El Bahy, 2013; Khan et al., 2018; Das et al., 2015), the measurement of mean body weight (Akter et al., 2016; Khan et al., 2018) and hematological value (Akter et al., 2016; Saha et al., 2015). The population, the ultrastructure and the protein profile of intestinal adult worms treated with Areca catechu crude aqueous extract have not been established up to the present.

The study aimed at investigating the population, the protein profile and the ultrastructure of adult worms in the intestine of domestic chicken treated using Areca catechu crude aqueous extract.

\section{MATERIALS AND METHODS}

All stages of the research were approved by the Ethical Committee of Gadjah Mada University (number 00126/04/LPPT/XI/2018).

\section{Preparation of The Extract}

The Areca catechu were obtained from a garden in Muntilan area of Magelang district of Central Java Province, Indonesia. They were sliced into small pieces and dried up (Mubarokah et al., 2019). The doses of $26 \mathrm{mg} / \mathrm{mL}, 53 \mathrm{mg} / \mathrm{mL}$ and $79 \mathrm{mg} / \mathrm{mL}$ were prepared from the Areca catechu crude aqueous extract. The dose of 26 $\mathrm{mg} / \mathrm{mL}$ was prepared from 2.65 grams of the sliced Areca catechu by adding $100 \mathrm{~mL}$ of aquades. And then, it was heated at $90{ }^{\circ} \mathrm{C}$ for 15 minutes. After that, it was cooled and filtered using filtering paper and kept in a refrigerator and used on next day (Widiarso et al., 2018).

\section{Experimental Chickens}

The animal experiments were carried out according to Aziz et al. (2018) with modifications. There were 50 female chickens of 6 weeks of age were used in the study. Adaptation period lasted for 14 days and on the day 15 the chickens were sterilized from protozoa and parasite infections treated with $\operatorname{Coxy}^{\circledR}$ and Levamid ${ }^{\circledR}$. Each chicken underwent worm's egg examination for each gram of its feces to make sure that it was free of any worm infection. They were raised individually in battery equipped cage, fed using commercial feed that contains coccidiostat (BR 2® medicated) and given drinking water ad libitum. They were assigned to 5 groups. The chickens in group A were not given any treatment and any drug. The chickens in group $\mathrm{B}$ were given the treatment at the dose of $26 \mathrm{mg} / \mathrm{mL}$ of the Areca catechu crude aqueous extract. The chicken in group $\mathrm{C}$ were given the treatment at the dose of $53 \mathrm{mg} / \mathrm{mL}$. The chicken in group $\mathrm{D}$ were given the treatment of 79 $\mathrm{mg} / \mathrm{mL}$. The chicken in group $\mathrm{E}$ were given Pyrantel ${ }^{\circledR}$ at the dose of $50 \mathrm{mg} / \mathrm{mL}$. Necropsy was conducted to all of the chickens 14 days after the treatment. The whole intestine was removed and dissected longitudinally. The adult worms in duodenum, jejunum, and ileum were collected in petri dish containing physiological $\mathrm{NaCl}$. The population of the A. galli in the intestine was counted on the basis of its location. 


\section{The Examination of Worms' Protein Profile}

The worms used in the study were those collected from the jejunum of the chickens in the treatment groups A, B and C. In short, the specimens were washed several times using Phosphate Buffered Saline (PBS) to remove impurity and chicken's tissue remnants. They were crushed in $250 \mu \mathrm{l}$ of PBS. The dissolved protein was insulated by centrifuging it at $1200 \mathrm{xg}$ for 5 minutes and then electrophoresis was carried out. Modified SDS-PAGE was carried out following Laemmli (Laemmli, 1970). The dissolved protein and the marker (Thermo scientific, Lithuania) were boiled for 2 minutes in sample buffer at $4: 1$ ratio, containing $50 \%$ of glycerol, $10 \%$ of SDS, $2.5 \%$ of DTT and $0.05 \%$ $(\mathrm{w} / \mathrm{v})$ of aqueous bromophenol blue as marker dye. The electrophoresis was carried out at $100 \mathrm{~V}$ in vertical slab gel system for 3 hours. Subsequently, the gel was stained using $0.2 \%$ $(\mathrm{w} / \mathrm{v})$ coomassie blue.

\section{Scanning Electron Microscopy}

The worms used in the study were those collected from the jejunum of the chickens' intestine. In short, the fixed specimens were washed using cacodylate buffer for 2 hours, and then the pre-fixation in $2.5 \%$ glutaraldehyde was carried out for 48 hours, the fixation in $2 \%$ tannin acid was carried out by washing the specimens 4 times with cacodylate buffer and distilled water, and finally, they were dehydrated in a series of ascending alcohols followed by drying in tertiary butanol. Dried specimens were coated using copper for 15 minutes and then observed in a SEM (JEOL JSM- 5319LV, JEOL USA, Inc.) (Sambodo et al., 2018).

\section{Statistical Analysis}

The data of the worms' population were analyzed using ANOVA test with IBM SPSS 16.0 software. The results of the analysis were expressed in mean \pm standard error. Meanwhile, the results of the SDS PAGE and SEM were descriptively analyzed. (Sambodo et al., 2018).

\section{RESULTS AND DISCUSSIONS}

\section{The Population of $\boldsymbol{A}$. galli Worms}

The populations of adult worms in each location are summarized in Table 1. The results of variance analysis showed that the treatment and location had a very significant effect $(\mathrm{P}<0.01)$ on the number of worms. There was a very significant interaction $(\mathrm{P}<0.01)$ between the treatment and the location and the number of the worms. The results of Duncan test of Alpha 0.05 show that there was significant difference $(\mathrm{P}<0.05)$ in the number of the worms among the three locations.

All of the doses of the Areca catechu crude aqueous extract show anthelmintic activity potential, except the dose of $26 \mathrm{mg} / \mathrm{mL}$. It is believed that the death of the adult worms in the study results from the presence of tannin contained in the Areca catechu crude aqueous extract. Various simple phenolic acids, including gallic acid, caffeic acid and flavonoid increase the tannin that is anthelmintic in nature (Mondal et al., 2015). The tannin may directly interact with the surface of the worms' body that directly or indirectly causes the damage of the worm by increasing protein nutrition and improving hospes' immune system (Min et al., 2003). It hampers fumarate reductase and succinate dehydrogenase enzymes that ATP synthesis in mitochondria is hampered. The hampered fumarate reductase and succinate dehydrogenase result in the obstruction of terminal electron acceptor that the formation of the succinate dehydrogenase is hampered and subsequently it results in ATP deficit. Consequently, it causes the death of the worms (Dhanraj and Veerakumari, 2016). The damaged membrane of the worms because of the tannin results in the paralysis and finally the death of the worms. Additionally, the tannin resulting from polyphenol is also able to precipitate protein in copolymer form that is insoluble in water (Susanti and Prabowo, 2014). The results of the study are consistent with those of the study by Akter et al. (2016) showing that the death of $87.5 \%$ of $A$. galli worms is caused by the treatment of pineapple leaf extract. Herawati et al. (2018) suggests that areca nut powder is able to eliminate $80 \%$ of the $A$. galli worms in chicken's intestine.

The biggest number of the A. galli worms is found in the jejunum, while the smallest one is found in the ileum. Based on the location of the worms, the results of the study are consistent with Ferdushy et al. (2012) suggesting that the location of the majority of the A. galli worms is anterior jejuno-ileum. Additionally, Prastowo et al. (2017) suggest that the biggest population of the adult $A$. galli treated using areca nut powder and Binahong (Bassela rubra linn) is found in jejunum. The location of the worms depends on infection period, the presence of other infections 
by other worm species and by bacteria (Ferdushy et al., 2012; Roepstorff et al., 1997).

\section{The Protein Profile of The Worms}

The protein profile of the worms in the treatment groups is illustrated in Figure 1. The negative control and the dose of $26 \mathrm{mg} / \mathrm{mL}$ give 21 protein bands with molecular weights of 131.6 $\mathrm{kDa}, 120.2 \mathrm{kDa}, 109.8 \mathrm{kDa}, 87.6 \mathrm{kDa}, 66.8 \mathrm{kDa}$, $63.8 \mathrm{kDa}, 58.3 \mathrm{kDa}, 53.3 \mathrm{kDa}, 46.5 \mathrm{kDa}, 44.4$ $\mathrm{kDa}, 40.6 \mathrm{kDa}, 35.4 \mathrm{kDa}, 32.4 \mathrm{kDa}, 29.6 \mathrm{kDa}$, $22.5 \mathrm{kDa}, 20.6 \mathrm{kDa}, 19.7 \mathrm{kDa}, 15,7 \mathrm{kDa}, 14.3$
$\mathrm{kDa}, 12.5 \mathrm{kDa}$, and $10.5 \mathrm{kDa}$, while the dose of $53 \mathrm{mg} / \mathrm{mL}$ gives 12 protein bands.

The difference may also result from the difference in protein concentration of each species of the worm used in the study. Kusnoto et al. (2001) suggest that the difference in the protein expression may relate to the genetics and the content of homogenate protein.

The decrease in the number of the protein bands at the dose of $53 \mathrm{mg} / \mathrm{mL}$ may result from the presence of the tannin in the Areca catechu crude aqueous extract. The tannin in its condensed

Table 1. The Population of Adult Worms According to Their Predilection Post Treatment

\begin{tabular}{lccccc}
\hline \multirow{2}{*}{ Site } & Control (-) & $\begin{array}{c}\text { Doses of } 26 \\
\mathrm{mg} / \mathrm{mL}\end{array}$ & $\begin{array}{c}\text { Treatments } \\
\mathrm{mg} / \mathrm{mL}\end{array}$ & $\begin{array}{c}\text { Doses of 79 } \\
\mathrm{mg} / \mathrm{mL}\end{array}$ & $\begin{array}{c}\text { Control (+) Pyrantel } \\
\text { pamoat } 50 \mathrm{mg} / \mathrm{mL}\end{array}$ \\
\cline { 2 - 6 } Duodenum & $27.6 \pm 3,98^{\mathrm{a}}$ & $19.4 \pm 11,99^{\mathrm{d}}$ & $0.7 \pm 1.16^{\mathrm{g}}$ & $0 \pm 0.00^{\mathrm{j}}$ & $0 \pm 0.00^{\mathrm{m}}$ \\
Jejenum & $52.3 \pm 9,31^{\mathrm{b}}$ & $37 \pm 21.79^{\mathrm{e}}$ & $1.3 \pm 2.21^{\mathrm{h}}$ & $0 \pm 0.00^{\mathrm{k}}$ & $0 \pm 0.00^{\mathrm{n}}$ \\
Ileum & $3.4 \pm 1.51^{\mathrm{c}}$ & $2.4 \pm 0.95^{\mathrm{f}}$ & $0 \pm 0.00^{\mathrm{i}}$ & $0 \pm 0.00^{\mathrm{l}}$ & $0 \pm 0.00^{\mathrm{o}}$ \\
\hline
\end{tabular}

${ }^{\mathrm{a}-\mathrm{o}}$ Different superscirpts in a column and row indicate significantly difference $(\mathrm{P}<0.01)$



Figure 1. Elektroferogram SDS PAGE of A. galli. Lane 1 marker protein, lane 2, 3 and 4 parasite sample proteins. (Mr: Marker; C(-): control negative) 
form has affinity to proline-rich protein, while nematode's cuticle is known to have proline-rich structure covering its body (Hoste et al., 2006). The proposed nematode controlling mechanism is that the tannin interferes with the physiological process of the nematode by directly binding the protein of the nematode and then blocking the physiological process of the parasite and/or modifying the immunity response of the hospes in eliminating infective larvae and adult worms (Zhong et al., 2014). The results of the negative control and the dose of $26 \mathrm{mg} / \mathrm{mL}$ are different from those of the study by Hargiyanto (2011) showing that there are 12 protein bands resulting from whole $A$. galli worm with the molecular weights of $293.8 \mathrm{kDa}, 236.9 \mathrm{kDa}, 115.6 \mathrm{kDa}, 75.1$ $\mathrm{kDa}, 60.6 \mathrm{kDa}, 42.3 \mathrm{kDa}, 23.8 \mathrm{kDa}, 16.7 \mathrm{kDa}$, $12.5 \mathrm{kDa}, 8,1 \mathrm{kDa}, 5.7 \mathrm{kDa}$ and $4.3 \mathrm{kDa}$.

\section{Scanning Electron Microscopy}

Figures 2-4 illustrate the ultrastructure of the worms treated using Areca catechu crude aqueous extract. The results of the micrography of the SEM show that there is a significant change in the ultrastructure of the $A$. galli after the exposure of the worms to the Areca catechu crude aqueous extract at the doses of $26 \mathrm{mg} / \mathrm{mL}$ and $53 \mathrm{mg} / \mathrm{mL}$ in vivo.

The change proves that there is an interaction between the Areca catechu crude aqueous extract and the cuticle that serves very important function for the nematode, especially for motility and absorption of certain nutrition. Hassain et al. (2009) suggest that in vitro test of the A. galli worms treated using C. micrantha indicates drastic change in mouth and cuticle. The change in the mouth relates to labia in which inflammation and damage take place on papilla sensory. Morphological damage takes place to the three labia ( 1 on dorsal part and 2 on subventral part). Morphologically, the labia become rounded or square, while the smallest labial accessory is separated from the 2 labial subventral parts. However, only a part of the labial accessory in the


Figure 2. The ultrastructure of Worm Anterior. a. Negative control: amphids structures were seen intact, b. Doses of $26 \mathrm{mg} / \mathrm{mL}$ : amphids structures were disfigurements (white arrow), c. Doses of $53 \mathrm{mg} / \mathrm{mL}$ : amphids structures were lost (white arrow) and adhesion (black arrow)
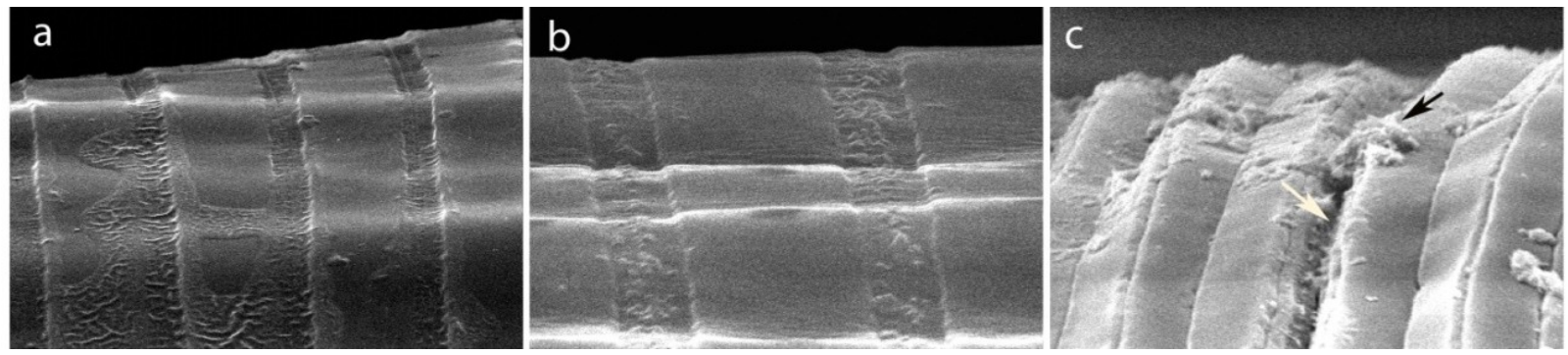

Figure 3. Cuticle ultrastructure of middle body of worm. a. Negative control: striations of annuli tranversal were regular, b. Doses of $26 \mathrm{mg} / \mathrm{mL}$ : striations of annuli tranversal were regular, c. Doses of $53 \mathrm{mg} / \mathrm{mL}$ : striations of annuli tranversal were irregular (white arrow) and abrasion (black arrow) takes place to cuticle 

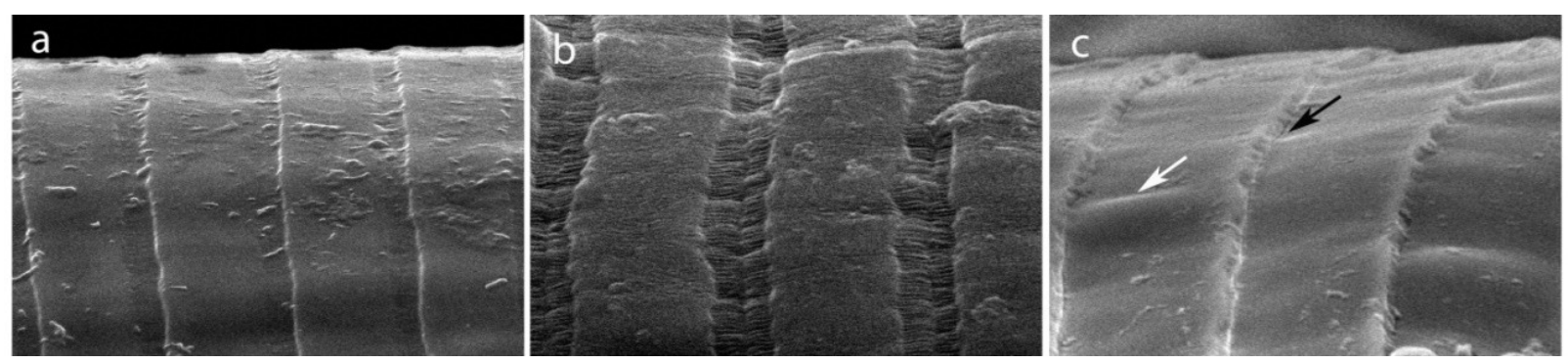

Figure 4. The Ultrastructure of the Cuticle of Worm Genital Sex Opening. a. Negative control: striations of annuli tranversal were regular, b. Doses of $26 \mathrm{mg} / \mathrm{mL}$ : striations of annuli tranversal were regular, c. Dosis $53 \mathrm{mg} / \mathrm{mL}$ : siltation (black arrow) and loosening (white arrow) take place to striation of annuli transversal groove

dorsal part is separated, while the remaining is still attached to its main part. The opening and the cavity of the mouth are clogged up by granulation tissue attached around the labia that results in the widening of the labia. Additionally, the formation of amphid vanishes because of the compressed labia. The cuticle groove around the labia vanishes because of the inflammation. Additionally, Lalchhandama (2010) suggests that the amphid represents the main chemosensory organ of the nematode and plays a very important role in its capability to recognize the behavior of the hospes and to control its development. The neurons found in the amphid are responsible for the majority of the sensory function such as detecting liquid chemoattractant, strong scent, heat receptor and chemotaxis (the movement resulting from stimuli) during the development of the larvae so that it can recognize the right hospes. The damage of the labia is usually caused by the damage of the amphids.

According to Hassain et al. (2009), $C$. micrantha has also significant impact on the cuticle structure that it influences the function of the culticle and results in the disruption of nutrition uptake and finally causes worm's death. The cuticle is a functional part of protecting and selecting in absorption function so that it becomes the main target of anthelmintic drug. Normal cuticle has annuli of continuous and well-ordered grooves that look like a ring, which stretch to posterior part. In preanal sucker part, the annuli do not connect to its irregular form (Lalchhandama, 2010). Additionally, the change in the cuticle into longitudinal and transversal wrinkles after the exposure to walnut extract rich of in vitro condensed tannin in Trichostrongylus colubriformis has been reported by Hoste et al.
(2006).

The affinity of the condensed tannin to protein is determined by the molecular mass and the molecular configuration of the tannin and also those of the protein. The tannin-protein bond is usually reversible. The $\mathrm{pH}$ (the acidity or the alkalinity), the treatment of detergent (surfactant) or phenol or other organic solvents can cause dissociation of a complex bond. The condensed tannin has special affinity to proline-rich protein such as gelatin, prolamin and the protein resulting from grains (Hoste et al., 2006). Also, it can interact with multiple lipid layers by binding cholesterol that may be found in the cuticle of some nematodes. The primary interaction of the condensed tannin may take place with cuticlines through the insertion of the condensed tannin into lipid layer (glycosylation). The secondary interaction with collagen proline-rich layer will result in further interference of hypodermal cells (Ropiak et al., 2016).

\section{CONCLUSION}

Areca catechu crude aqueous extract has a significant anthelmintic activity potential in reducing the number, lowering the protein profile and causing serious damage to adult A. galli worms in chicken's intestine.

\section{ACKNOWLEDGMENTS}

The authors are grateful to the Office of Agriculture Human Resources Development and Agriculture Extension, the Ministry of Agriculture of the Republic of Indonesia for the financial support through a Domestic Graduate Scholarship Grant Number 198/ Kpts/Kp.320/2/2018. 


\section{REFERENCES}

Akter, M.K., A.B.M.J. Uddin, M. Rashid, F.B. Aziz, Md.B. Rashid and M. Hasan. 2016. Studies on prevalence of ascariasis in indigenous chickens in Gaibandha District and treatment by pineapple leaves extract. Res. Agric. Livest. Fish. 3(1):157-163.

Alkharigy, F.A., S. Adnan, El Naas and A.A. El Maghrbi. 2018. Survey of parasites in domestic pigeons (Columba livia) in Tripoli, Libya. Open Vet. J. 8(4):360-366.

Aziz, A.R.A., M.R. AbouLaila, M. Aziz, M.A. Omard and K. Sultan. 2018. In vitro and in vivo anthelmintic activity of pumpkin seeds and pomegranate peels extracts against Ascaridia galli. Beni-Seuf Univ. J. Appl. 7(2):231-234.

Balqis, U., M. Hambal, Rinidar, F. Athaillah, Ismail, Azhar, H. Vanda and Darmawi. 2017. Cuticular surface damage of Ascaridia galli adult worms treated with Veitchia merrillii betel nuts extract in vitro. Vet. World. 10(7):732-737.

Bazh, E.K.A. and N.M. El-Bahy. 2013. In vitro and in vivo screening of anthelmintic activity of ginger and curcumin on Ascaridia galli. Parasitol Res. 112(11):3679-3686.

Das, M., R. Laha, A. Goswami and S. Doley. 2015. Gastrointestinal parasitism in turkeys and quails of Umiam, Meghalaya. Indian J. Hill Farm. 28(1):12-13.

Dhanraj, K.M. and L. Veerakumari. 2016. Effect of ethanol extract of Areca catechu on fumarate reductase and succinate dehydrogenase of Cotylophoron cotylophorum. Int. J. Res. Dev. Pharm. Life Sci. 5(3):2117-2123.

Ferdushy, T., P. Nejsum, A. Roepstroff, S.M. Thamsborg and N.C. Kyvsgaard. 2012. Ascaridia galli in chicken: intestinal location and comparison of methods to isolate the larvae within the first week of infection. Parasitol Res. 111(6):2273-2279.

Hargiyanto, W. 2011. Protein Profile of Ascaridia galli Adult Worm With SDS-PAGE method: Abstract. Skripsi-Thesis. Universitas Airlangga, Indonesia.

Hassanain, M.A., A. Rahman and F.A. Khalil. 2009. New scanning electron mocroscopy look of Ascaridia galli (Schrank, 1788) adult worm and its biological control. Res. J. Parasitol. 4(4):94-104.
Herawati, O., Kurniasih and J. Prastowo. 2018. Effect of jambe (Areca catechu) powder in comparison with combination of jambe powder and binahong (Anredera cordifolia) to ascariasi infestation on poultry. Jur sain vet. 36(1):88-94.

Hoste, H., F. Jackson, S. Athanasiadou, S.M. Thamsborg and S.O. Hoskin. 2006. The effects of tannin-rich plants on parasitic nematodes in ruminants. Trends Parasitol. 22(6):253-261

Husori, D.I., Sumardi, H. Tarigan, S. Gemasih and S.R. Ningsih. 2018. In vitro anthelmintic activity of Acanthus ilicifolius leaves extracts on Ascardia galli and Pheretima posthuma. J. Appl. Pharm. Sci. 8(2):164167.

Khan, A., H. Tak, R. Nazir and B.A. Lone. 2018. In vitro and in vivo anthelmintic activities of Iris kashmiriana Linn. J. Saudi Soc. Agri. Sci. 17(3):235-240.

Kusnoto, S. Subekti, I.K. Sudiana and Soedarto. 2001. Characterization and isolation of specific protein of Excretory-Secretory (ES) material from Toxocara cati to the Development of Diagnostic Toxocariasis by ELISA Technique. J. Biosains Pasca. 13(1):56-65.

Laemmli, U.K. 1970. Cleavage of structural proteins during the assembly of the head of bacteriophage T4. Nature. 227(5259):6805.

Lalchhandama, K. 2010. On the structure of Ascaridia galli the roundworm of domestic fowl. Sci Vis. 10(1):20-30.

Min, B.R., T.N. Barry, G.T. Attwood and W.C. McNabb. 2003. The effect of condensed tanins on the nutrition and health of ruminants fed fresh temperate forages: a review. Anim. Feed. Sci. Tech. 106(1-4):319.

Mondal, H., H. Hossain, K. Awang, S. Saha, S.M.U. Rashid, M.K. Islam, M.S. Rahman, I.A. Jahan, M.M. Rahman and J.A. Shilpi. 2015. Anthelmintic activity of ellagic acid, a major constituent of Alternanthera sessilis against Haemonchus contortus. Pak Vet J. 35(1):58-62.

Mubarokah, W.W., W. Nurcahyo, J. Prastowo and K. Kurniasih. 2019. In vitro and in vivo Areca catechu crude aqueous extract as an anthelmintic against Ascaridia galli infection in chickens. Vet. World. 12(6):877-882. 
Prastowo, J., O. Herawati, B. Ariyadi and Kurniasih. 2017. Effects of Areca catechu seed and Anredera cordifolia leaf on Ascaridia galli infectionin the domestic chicken (Gallus gallus domesticus). Int. J. Poult. Sci. 16(12):494-499.

Roepstorff, A., L. Eriksen, H.C. Slotved and P. Nansen. 1997. Experimental Ascaris suum infection in the pig: worm population kinetics following single inoculations with three doses of infection eggs. Parasitol. 115(4):443-52.

Ropiak, H.M., O. Desrues, A.R. Williams, A. Ramsay, I. Mueller-Harvey and S.M. Thamsborg. 2016. Structure-activity relationship of condensed tannins and synergism with trans-cinnamaldehyde against Caenorhabditis elegans. J. Agric. Food Chem. 64(46):1-40.

Saha, B.K., Md.A. Al-Hasan, M.A. Rahman, Md.M. Hassan and N. Begum. 2015 Comparative efficacy of neem leaves extract and levamisole against ascariasis in chicken. Int. J. Nat. Soc. Sci. 2(2):43-48.

Sambodo, P., J. Prastowo, K. Kurniasih and S. Indarjulianto. 2018. In vitro potential anthelmintic activity of Biophytum petersianum on Haemonchus contortus.
Vet. World. 11(1):1-4.

Susanti, A.E. and A. Prabowo. 2014. The potential of pinang (Areca catechu) as an anthelmintic for livestock. Proceedings of the National Seminar on Environmentally Friendly Agriculture Supporting Bioindustry in Palembang Sub-Optimal Land. September 16th 2014. p404-409.

Vercruyssea, J., M. Albonico, J.M. Behnke, A.C. Kotze, R.K. Prichard, J.S. McCarthy, A. Montresor and B. Levecke. 2011. Is anthelmintic resistance a concern for the control of humansoil-transmitted helminths?. Int. J. Parasitol Drugs Drug Resist. 1(1):14-27.

Widiarso, B.P., W. Nurcahyo, Kurniasih and J. Prastowo. 2018. The effect of apus bamboo (Gigantochloa apus) leaves infusion on mortality rate and morphometry of Haemonchus contortus adult worm in vitro. Indonesian J. Vet. Sci. 11(4):156-159.

Zhong, R.Z., H.X. Sun, H.W. Liu and D.W. Zhou. 2014. Effects of tannic acid on Haemonchus Contortus larvae viability and immune responses of sheep white blood cells in vitro. Parasite Immunol. 36(2):100 106. 